\title{
A.JOTE
}

African Journal of Teacher Education

ISSN 1916-7822. A Journal of Spread Corporation

Vol. 7 No. $12018 \quad$ pp. 53-65.

\section{Teaching Art Music in Nigerian Schools: The Academic, Technical and Social}

\section{Implications}

\author{
Dr. Femi Sinaola Abiodun ${ }^{1}$ \\ Music Department, \\ Obafemi Awolowo University, \\ Ile-Ife, Nigeria
}

\begin{abstract}
Art music in the Nigerian context is the composition of Nigerians who have formal music training and have composed using Western medium to express traditional Nigerian music. This paper sets out to illuminate the technicalities involved in this form of musical composition and proposes a model of art music instruction for Nigerian schools. The author posits that the teaching and performing of art music in Nigerian schools will bring music closer to the people. He argues that whereas art music is an aberration from Nigerian traditional music, yet with concerted efforts and skill, the practice of art music will help in preserving Nigerian culture on paper and facilitate the promotion of its local music to the global level. The paper concludes that traditional music elements that are entrenched in art music composition can constitute a model and parameter for identifying and appreciating Nigerian music. The teaching of art music therefore must be encouraged by Nigerian music curricular planners.
\end{abstract}

Keywords: Art music, Nigerian school, Traditional Music, music composition, art musicians.

\footnotetext{
${ }^{1}$ Dr. Femi Abiodun is a faculty staff of the Department of Music, Obafemi Awolowo University, Ile-Ife Osun State Nigeria where he teaches Tonal Counterpoint, Conducting, African Music and Performance with emphasis on intercultural musicology. Publications include journal articles and chapter contributions in Ethnomusicology and Music Education. He has a research background in African Music Theories where he intends to develop contrastive musicology theories. An accomplished organist, he has directed and conducted choral and music theatre performances. He currently serves on the editorial board of Pan-African Music Education Arts, South Africa and the editorial board of journal of Association of Nigerian Musicologists and Nigerian Music Education Journal. He is the past National Secretary of the Association of Nigerian Musicologists
} 


\section{Introduction}

Our pride as Africans is our tradition. While Africa may for now not be able to contest with the Western world in technology, we should handle our tradition with care in the face of modernization, acculturation, and globalization. Musical art education can help us to improve our tradition and promote our culture. Nigeria's development objectives as they are contained in the $4^{\text {th }}$ National development plan (section H) calls for "greater self-reliance". This is a call for increased dependence on our own resources in seeking to achieve the various objectives we set for our societies. One of such acclaimed resources is our culture - the material expression of a people as well as the process with which the expressions are communicated (Oyeneye 1984, 60). Traditional music can be defined as the non-material expression of a people and the process through which such non-materials expressions are communicated. Teaching all aspects of our culture, including our traditional music, is a process of communication, socialization and development.

Each ethnic group in Nigeria has music that is peculiar to its culture and such music is produced according to local norms, mores and rites. Traditional or indigenous music is a representation of all cultural vocal and symphonic expressions that make up the particular society, including the society's skills, arts, instruments and institutions. Chernoff $(1979,79)$ asserts that music in African traditional setting is a representation of the people's culture, a replica of their life pattern and that the study of a people's music can offer an especially valuable approach to her culture.

Art music is a composition written by people who have been influenced by European classical music tradition - involving the application of formal, structural, and theoretical considerations. Omojola (1995) describes it as "music in which a great deal of attention is given to the musical, technical or artistic interest of the piece as a focus of aesthetic enjoyment" (p.6). Art music is a composition committed to paper and can be performed across the globe by people who have the "magical knowledge" of music theory. Whereas traditional Nigerian music is oral and can be performed only effectively within the cultural area where it is passed on orally from one generation to another.

This paper therefore analyses the technicalities, academic intricacies and social implications of music as represented in art music compositions. Premised on structuralist/functionalist theory, the following are the research questions that are pertinent to the arguments in the paper: What conceptual framework differentiates art music from traditional music performance? How does the 
difference in the medium of performance affect the mind-set of an African? Are the functions and usage of music in the life of an African represented in the composition and how are these phenomena represented in the performance of art music compositions? What will the dissemination of information through art music compositions accomplish for the music teacher? How do all these affect the teaching of art music in Nigerian classrooms?

\section{Features and Elements of Nigerian Traditional Music}

Traditional music is the practice of what is musical and extra- musical in the culture of a people. It is constituted by the musical activities of a people, devoid of any outside influence whether in strict festive mood or in a relaxed situation. Traditional Nigerian music involves performers within the community disseminating via musical performances vital information related to their world. Music as cultural expression is a social force that acts as a socialization agent. A traditional musical performance displays three explicit functions:

a. disseminates information

b. provides an avenue to relate with others within and outside the community

c. servers as a socialization agent.

Other latent functions of traditional music include the therapeutic functions for the troubled or sorrowful mind, the soothing of psychiatric and psychosomatic disorders, its provision of ritual and spiritual healing and its creation of a medium of theosophical prayer to develop a special relationship between a soul and God. Abiodun (2011) has documented how in the Oyo, Ife Yoruba community in Nigeria, sick people were healed when they sang and were exposed to singing at the shrines of the local deities. He has documented mental health or psychiatric patients recovering from their ailments when brought to the palace of adamu orisa [masquerade shrine] where they engaged in singing in the context of traditional musical performance.

The utilitarian functions of traditional music include the entertainment it provides at social gatherings, its expressions of local feelings and thoughts, its keeping traditions alive, its exhibition of culture, its serving as a means of livelihood, and its promotion of artistic expression. One of the main features of Nigerian traditional music is its close association with the social context. They are always related to events out of which they are born and established. A typical traditional music could only have meaning in association with the socio-cultural institutions that produces it and through which it is expressed. Euba (1963) asserts that 
One of the most important factors of keeping traditional music alive in Nigeria is the continuity of the various social institutions, which serve as the basis for the performance of this music. As long as these institutions remain active, there is little fear that the practice of traditional music will seriously decline (p.475)

Nigeria's traditional music structure and styles are different from Europe's. Its style features flexibility in its pitch system, i.e., it is based on a relative rather than a fixed pitch system. Its scales comprise majorly five notes (Pentatonic) with no semitone interval (anhemitonic pentatonic). Its melodic level features sharp interval rises followed by slow descents. Its form is binary with the two parts built about different tones in the scale call and response pattern (antiphonal). Its melody makes use of offbeat phrasing of melodic accents "with a limited range and 'supposedly in the same [tonal] key" (Agawu, 2011).

Nigerian languages are inflectionary, and they are a force to reckon with in determining the melodic contour and rhythmic pattern (vocal and instrument) of many African melodies. The technicality lies in the fact that in many of the melodies the tones determine the pitches. The Yoruba language has three tone levels (high-me middle-re and low-doh). Akpabot (1986) affirms that "an African instrumental music borrows much from vocal music which in turn is tied to speech melody and speech rhythm". Speech melody and speech rhythms are interrelated in African traditional music. The interrelatedness calls for attention because it forms the nucleus of the complexity of African music. Being a technical issue, it must be well represented in the art music composition and within the traditional music framework if the music will make meaning to the African audience.

Traditional music is as old as the community that owns it. It is a communal practice. Nzewi (1991) reiterates that "it is not an experience to be enjoyed in isolation without other human beings" (p.96). This also is the position of John Blacking in his book How musical is man? It is part of their life pattern and a close study of a people's music would reveal their socio-religious life in a given time. Traditional societies of Nigeria once had their music practiced within their culture before the advent of Arabic and European cultures. What music meant to them was more than mere entertainment; it did more than to sustain social or celebratory functions. It was also ritualistic in nature (Sowande 1967, Olukoju 1987, Adegbite 1988, Meki 1991, Vidal 2012 and Abiodun 2011). Of note is Sowande's assertion that Music was 
(1) as evocative or creative in its own right and as itself (2) the organization of the raw materials of sound into formal structural pattern that are meaningful and generally acceptable to that society in which the organization has taken place (3) that traditional music is functional at root because it enabled its creator and practitioners to bridge the gulf between the visible and invisible worlds. (1967, p.245)

Traditional music then also functions to evoke the spirit of the gods, entertain during moonlight plays, correct the social ills in the society and more importantly praise the king and chiefs. Such music includes ritual songs, praise songs, songs of insults and recreational songs which are performed by musicians and composers in the palace, or by war musicians, cult musicians and or griots. The traditional musical instruments found in the palaces, shrine of the gods, among the music family, the griots and the hunters were used to accompany the music.

With the intrusion of different foreign cultures, Nigerian traditional music assumed a new outlook in its practice, production, functions and performances. Its musicians changed, its instrumentation changed, its song texts changed, but the institutions that own the music did not change. However, as Euba (1963) asserts, even "a discontinuation of these institutions would not necessarily mean death of the music for it is already apparent that in whatever ways, traditional music will continue to thrive on its own" (p.248). The effort of the art musicians, in this regard, would be complementary to preserving traditional music.

Nowadays, Nigerian traditional music has also witnessed a dramatic change in the hands of the art musicians. They have successfully fused elements and styles of traditional music with those of European music. In doing so, they re-interpreted elements of traditional music and fussed them into European idioms. They now use diatonic harmonic scales; adopt and adapt folk tunes; appropriate Nigerian rhythmic pattern; they join together sharply contrasting styles, use dissonant intervals, and have adapted traditional call and response musical structure, in addition to their fusing of Nigerian and European instruments in their performances.

While, the first set of trained art musicians worked successfully to fuse the two cultures into their musical works, they never thought of writing in Nigerian traditional musical forms only. Sowande (1967) who gave a lot of thought to this concluded, "We are not prepared to submit to the doctrine of 'apartheid' in art by which a Nigerian musician is expected to work only within the limits of his traditional forms of music" (p.251). It is expedient for the Nigerian composers 
therefore to move along with the global trend that is witnessed in composing in new musical styles. One of such is the Nigerian art music.

\section{The Technical Issues in art music composition and the Implications for Teacher Education}

This study dictates technical, theoretical, social and practical implications for music educators in the areas of art music pedagogy and assessment. The social considerations are in the submission of Y. S Onyiuke and Emmanuel C. Umezinwa (2012)

i. that traditional music remains a vital feature of the people's life.

ii. that music in Nigerian tradition has never been mere sonic object. It has always been associated with life and functions in the lives of people as integral part of events.

iii. that transmission was through the process of imitation.

iv. the non-formal system of learning was apprenticeship which took a long time.

v. that cross-cultural contacts affected the music of people.

vi. that a relationship existed between a people and their language, dance, costume, way of life and their instruments.

vii. that traditional music was never meant for purely commercial purposes.

viii. that the absence of notation ensured the survival of improvisation and variations.

ix. that traditional music is embedded in the texts, lessons of life, folklores, histories and epics and values of the people all wrapped into one.

x. that the absence of a written system of notation and highly formalized teaching and learning structures did not affect the artistic, aesthetic and therapeutic values of traditional music

One of the main challenges for Nigerian art music teachers is that they be able to interpret Nigerian art music within African religious, social, cultural, and philosophical contexts. This implies that, for instance, art music performance should showcase the identity functions of Nigerian traditional music. Realizing art music on stage becomes a challenge to music teachers in Nigeria.

These technical and theoretical issues fall within the sphere of definitions and structural consideration of art music in Nigeria. Art music refers to musical traditions with structural and theoretical considerations and a written tradition. The implication of this is that the technical-knowhow makes it different from traditional performances. Teachers should teach these technical elements through accurate interpretation and analysis. Philip Tagg's definition of art music as "an axiomatic triangle consisting folk, art and popular music" requires additional technical application. 
This definition differentiates art music from folk/traditional and popular music in the Nigerian context. Many musicologists and scholars in Nigeria, a first school of thought, accept this definition. Another school of thought, scholars in critical musicologist movement, rejects the latent social elitism associated with the definition. Scholars in music theory define art music as music which requires significantly more work by the listeners to fully appreciate the music (Russell and Schmidt-Jones, 2005). Teachers in secondary schools in Nigeria must stand up to face these definitive challenges in their practical and functional practices.

The hypothesis that art music is superior to other genres of music is debatable. This hypothetical statement has been tested in a comparative study of art and traditional music structures (Abiodun 2011). The result generated a lot of arguments among scholars in Nigeria. One position is that the traditional and the art music have all the basic elements- melody, rhythm, form and harmony. This school of thought faces a lot of criticism from ethnomusicologists in Nigeria who assert that no matter the technicality and difficulty of a music, each musical tradition has the same element of dignity and no one can claim any superiority over others. The music teacher should identify these basic elements and through analysis examine the structure of each as an entity. Other related technical issues about art music are that

i. It has a classical tradition which focuses on formal styles

ii. It demands focused attention from listeners, music teachers need to prepare the mind of the listener to listen with rapt attention in the music appreciation class.

iii. It is a written musical tradition. Teachers must therefore teach the students to read music in regular workshops to sensitize the public about the new medium of performance.

iv. It is a written tradition preserved in some form of notation as different from the orally transmitted or recordings like the popular music. The new trend about art music is that its identity is usually defined by notation version rather than performance of it. Some art music may deviate from the classical music standard by employing new types of notation to facilitate new performance form. Nigerian Music teachers should explore the element of formality to interpret the content of the work. Teachers need to understand these primary but concerted and conceptual challenges.

As defined by Abiola Irele, African art music is "a conscious and elaborate form...bound to the musical language of Europe" (1993, 61). By and large, its primary exponents are African 
composers with varying degrees of training and immersion in European classical music. Modern African art music provides such composers with a tool for working out their contemporary Africanness, what Irele calls elsewhere, their "dual experience" of tradition and modernity. Such a working out entails the recontextualization of traditional African musical elements and values within the literate medium of European art music. Works produced are often conceived for performers who are similarly accustomed to the norms of European art music, in venues such as theatres and concert halls where performer-audience boundaries are clearly marked.

This sharp contrast from Irele's definition should not pose a problem to Nigerian teachers who are also trained in European classical music. However, unlike the performance in European theatres, Nigerian performance should use the dual experience acquired to bring out the Africanness in such composition. The Nigerian art musicians of the 20th century have done a lot in establishing Nigerian art music as a form different from other forms of music in Nigeria-pop, reggae, blues, jazz, high life, fuji, juju etc which are products of acculturation. The present Nigerian art music is a fusion of Nigerian and European idioms arrived at after several attempts by the art musicians who have had to overcome "myriads of challenges" ranging from rejection, criticism, and jettisoning of their work. Such art music performed within the classroom arena, face challenges that include imposing Western melodies on Nigerian words. For example, in the Igbo experience, a word like odunma (it is fine) would imply a different meaning when a musical note is imposed on it. (Ekwueme 1983). In the Yoruba example, a word like $e$ wa (come) would sound differently as ewa (beans) Vidal (2012). The effect of this was miscommunication resulting from super-imposing a European tune on Nigerian texts. Other relative technical challenges of teaching and learning art music in Nigerian schools include:

i. The inability of Nigerian traditional drummers to read music. The scores produced cannot be performed by the practitioners at the local levels. The effort, to many of them interviewed is meaningless and according to them does not contribute to the development of traditional music at that level.

ii. The non-availability of Nigerian traditional musicians in Nigerian universities, making it almost impossible to collaborate in the performance of art music in the classroom. Art music composers need to carry along the traditional practitioners especially when such compositions are to be performed. The music teachers should be the link in this direction. 
iii. Demand for such music is low because of the musical medium which is different from the traditional practice.

Other challenges itemized by Ekwueme (2004, p.283) include:

i. The limitation in structural organization imposed by the strict call and response

ii. The limitation of the traditional range of Nigerian songs

iii. Problems of tonality and intonation

iv. No audience for the music

Solutions to these challenges can be found in our classrooms where the knowledge of musical art education can be imparted. Other problem areas to note are that Western notation system is inadequate for a representation of what a Nigerian music is and there has not been a generally accepted form of notation for Nigerian music. For now, the professional art musicians in Nigeria has adopted the staff notation system. This has enhanced the performance of Nigeria music across the globe.

There is equally little or no information about Nigerian musical elements like rhythmic, melodic, harmonic patterns, and textural devices, etc. The few ones that are available were "arrived at" by European scholars who, according to Akpabot (1998), have arrived at conclusions that are a mixture of accuracy, speculations, approximation, misinformation and dogmatism (p.2). There has not been a thorough investigation of the correlation between the practice of traditional music and the structure of the music as reproduced in art music. Meki (1991) observes that "systematic African musical art studies are inchoate" (p.4).

Art composition has not convincingly represented Nigerian culture. These hints given above about the position and technicalities of art music in Nigeria would form the basis for discussing the solutions. Three fundamental principles that would aid the process of its usage in Nigerian schools and make it functional within the social context are recommended as a model of art music instruction for Nigerian schools:

\section{Structural rehabilitation}

By structured rehabilitation, we mean putting the music in 'good condition' in order to restore to original performance contexts. These can be done in the following ways: 
i. Formation of different symbols of notation that will accommodate what the present staff notation cannot contain.

ii. Use of Nigerian melody and rhythmic idioms with little or no distortion of the melodic contour patterned after the intonation of African text. This will retain the meaning of the Nigerian texts.

iii. Use of parallel harmony where conventional harmony will distort the flow of the music.

iv. Actual interpretation of what the music represents in the community and within context of performance.

v. Training of Nigerians to play Nigerian instruments from notation

\section{Total activation}

Total activation means bringing into use all the traditional music genres already ignored or made inactive by acculturation.

These include:

i. Use of our traditional instruments in our schools

ii. Construction and maintenance of traditional instruments anchored by the teachers

iii. Preservation of the tradition in theory and practice

iv. Performing the music regularly at home (Nigeria) and abroad

v. Participating in the events that are associated with the traditional music. Teachers organizing visit and participation in musical and non-musical events at the local levels

\section{Pragmatic propagation}

Pragmatic propagation means spreading Nigerian art music and influencing a great number of people across the globe. These include:

i. Publishing our musical compositions and making them available for use in our schools.

ii. Recording our compositions and performances on different media devices and making them available in all media houses at national and international levels, and especially on the internet. This is a task the music teachers must do.

iii. Commercializing our recordings for mass commercial market, a situation which will not only boost the economic power of art musicians but will make their music readily available to the mass.

iv. Staging regular performance of the art music that includes the traditional practitioners. Even though home videos and film have almost paralyzed stage performance, performing art 
compositions will close the gap between the trained musicians and the traditional practitioners.

v. Giving it a radio and television broadcast will also allow the Nigerian populace to get familiar with what art music is - its theory and practice.

\section{Conclusion}

This paper concludes that the academic, technical and social challenges in teaching art music in Nigerian schools notwithstanding, art music has attained this so much level of fame in the art music world in the hands of none other than art musicians who had training in European music. The Nigerian traditional music's notation and analysis, in terms of melody, rhythm, scale, harmony etc. were done in relation to Western music idioms. Hence, Omojola (1995) warns that "European elements should not be discouraged in modern African works, but [that] they should not suppress the African features used in such works" (p.64). The performance of Nigerian art music should be made to activate the functions and usage of the music in the life of an African as represented in the composition.

Nigeria should be more independent than ever; she should be more consistent in the development of her culture. Traditional music is a living art and a structured rehabilitation of its style, a total activation of its elements, and pragmatic propagation of its performance within the framework of art music would make it practical and functional rather than decorative art.

\section{References}

Abiodun, Femi (2011). Melodic Patterns and Song Forms in Ekiti Musical Traditions. Journals of the Association of Nigerian Musicologists. No. 6 Pp 40-50

Adegbite, Ademola (1988). "The Drum and its Role in Yoruba Religion”. Journal of Religion in African. pp. 17-25.

Aguwu, Kofi (2011). "The Challenge of African Art Music" Circuit: musiques contemporaines, vol. 21, n.2 pp. 49-64

Akpabot, S. E. (1986). Foundation of Nigerian Traditional music, lbadan: Spectrum Books Akpabot, S.E. (1998). Form. Function and Style in African Music. Ibadan: Macmillan Nigeria Publishers.

Biobaku, Saburi (1983). "The Role of Culture in National Development in Iwara Alex (Ed) 
African Notes Vol. ix No. 2, Ibadan: Heinemann books.

Blacking, John (1976). How Musical is Man? Great Britain: Faber and Faber Ltd.

Chernoff, M. J. (1979). Africa Rhythm and African Sensibility. Chicago: The University of

Chicago Press.

Ekwueme, Laz (1983). African Music in Christian Liturgy: The Igbo Experience. African Music

Vol. 5 (3) pp. 1-17

Ekwueme, Laz. (1983). Choir Training and Choral Conducting. Lagos: Lenaus

Publishing Ltd. Lagos.

Ekwueme, Laz (2004). Composing Contemporary African Choral Music: Problems and

Prospects" Essays on the Theory of African Music. Lagos: Lenaus Publishing Limited. Pp 281-320

Euba, Akin (1963). "Music in Traditional Society" in Adebayo (Ed) Nigerian Magazine No. 78,

Lagos: Federal Ministry of Social development, Youth and Culture.

Irele, Abiola (1993). "Is African Music Possible” Transition 61 pp. 56-71

Meriam, Alan. P. (1982). African Music in Perspective. London: Garland Publishers. Inc.

Nesbitt Nick (2001). African Music Ideology and utopia. Research in African Literature Vol. 32

(2). Downloaded from 197.253.6.248

Nzewi, Meki (1991). Musical Practice and Creativity: An African Traditional Perspective.

Germany: Bayreuth IWALEWA-Haus, University of Bayreuth

Olukoju, E. O. (1987). "Music in Religious Worship.” Orita: Ibadan Journal of Religious

studies. Vol. Xix ( 2) pp. 118-1333

Omojola, Bode (1995). Nigerian Art Music. Ibadan: I. F. R. A.

Onyiuke, Y. S and Umezinwa, Emmanuel C (2012) Nigerian Traditional Music Education in the Context of Global Educational Challenges Copyright (C) IAARR 2012: www.afrrevjo.net 89 Indexed African Journals Online: www.ajol.info

Oyeneye, O. Y. (1984). “Indigenous Cultural as Basis for Nigeria's Development” in Falola T. (Ed) $O D U$ No. 25.

Russell Jones and Schmidt-Jones Catherine (2005). Introduction to Music theory. Accessed February 8, 2016. http: Ilwww.amazon.com

Sowande, Fela (1967). "Nigeria Musicians: Then and Now" in Adebayo (Ed) Nigeria Magazine No. 94, Lagos: Cultural Division, Ministry of Information. 
Tagg, Philip (n.d.). Analysing Popular Music: Theory, Method and Practice. Popular Music 2 pp. 37-65; http://www.tagg.org. Accessed February 8, 2016

Vidal, Tunji (2012). “The Westernization of African music: A study of Yoruba Liturgical Church Music.' Essays on Yoruba Musicology. Ile-Ife: University of Ife Press. pp.24-36 